\title{
COMPARATIVE CHARACTERISTIC OF ULTRASOUND CHANGES OF THYROID GLAND IN CHILDREN WITH DISTURBED AND NORMAL HEART RHYTHM ${ }^{*}$
}

\author{
T. Ye. Shumna ${ }^{1}$, S. M. Nedelska ${ }^{1}$, K. S. Shmatko ${ }^{1}$, O. G. Alekseev ${ }^{1}$, I. O. Zhilenko ${ }^{1}$, \\ T. V. Tarasevich ${ }^{1}$, T. V. Abramova ${ }^{1}$, A. S. Merezhko' , A. V. Shapran ${ }^{2}$, R. I. Kamagina ${ }^{2}$ \\ ${ }^{1}$ Zaporizhzhia State Medical University, Zaporizhzhia, Ukraine; \\ ${ }^{2}$ Municipal Non-Profit Enterprise "City Children’s Hospital № 5" of Zaporizhia City Council, \\ Zaporizhzhia, Ukraine \\ tshumnaya72@gmail.com
}

Thyroid gland is an endocrine gland, which function influences the work of the whole body, because thyroid hormones support the work of the brain, heart, muscles and bones, the reproductive system and play an important role in the metabolism [1, 2]. At the same time, thyroid hormones help to increase the volume of circulating blood and raise the use of oxygen by myocardium, and if its utilization from the blood does not increase herewith, it can lead to a violation of metabolic and enzymatic processes in the myocardium $[3,4]$.

Since every child who comes to the doctor for any reason always undergoes in an objective study auscultation of the heart, the initial diagnosis of cardiac rhythm disturbances presents no big difficulties. However, the true etio- logical factor in the occurrence of arrhythmias in children is far more complicated, especially taking into consideration that far more often than cardiac cases, extracardiac causes are recorded, including the side of the endocrine organs.

Therefore, a very important issue is the timely diagnostics of the least changes in the thyroid gland. The examination of the thyroid gland itself includes visual and palpation assessment of its size, shape, consistency. However, pathological changes in the thyroid gland are not always immediately accompanied by a change in the volume or texture of the organ, and changes in the tissue structure of the thyroid gland occur more often than the violation of its function. Therefore, the ultrasound

* The presented research is a fragment of the scientific and research work of Faculty Pediatrics Department of Zaporizhia State Medical University: «Optimization of differential diagnostics and treatment of allergic and other diseases in children of different ages» (state registration number - 0118U004254), 2018-2022 years.

Institution, which financed the research: Ministry of Health of Ukraine.

The authors assume responsibility for the published work.

The authors guarantee absence of competing interests and their own financial interest when carrying out the research and writing the article.

The manuscript was received by the editorial staff 29.08.2019. 
diagnostics, including morphological analysis, functional dopplerography, color Doppler and energy mapping has become the main non-invasive method of thyroid gland examination [5].

Almost all significant violations of the thyroid gland function are reflected in various changes in its structure. These may be diffuse changes in the parenchyma, an increase in the volume of the organ or its lobes, thickening of the isthmus, the presence of inclusions, follic- les, nodules, or just a significant increase in local blood circulation in the gland tissue [6-8].

\section{Purpose}

Determination and comparative characteristic of ultrasound changes of thyroid gland in children with disturbed and normal heart rhythm to justify the need for a ultrasound screening study as a method of early diagnosis and prevention of thyroid pathology.

\section{MATERIALS AND METHODS}

During the work performance the ultrasound examination of the thyroid gland has been carried out for 142 children, including 75 girls and 67 boys aged from 3 to 17 years old. Out of these number 118 children (63 girls and 55 boys) with cardiac activity, namely, cardiac rhythm, confirmed by electrocardiography and Holter monitoring were included in Observation group I, the second Comparative group included 24 children with normal heart rhythm (13 girls and 11 boys). The ultrasound evaluation of the thyroid gland was performed using the ultrasound machine «Esaote MyLab50» with a linear sensor with a frequency of 7.5-12 $\mathrm{MHz}$ according to the generally accepted Brunn method, which consists of determining the three dimensions of the length, width and height of the ultrasound, and the determination of the volume by the formula of ellipse $(0,479 \times \mathrm{A} \times \mathrm{B} \times \mathrm{C})[9,10]$. Statistical processing of data was carried out using conventional variational statistical methods using a licensed software package Statistica for Windows 6.1.RU, serial number AXXR712D833214SAN5. We used nonparametric statistical methods: the $« 2 \times 2$ Table», the Chi-square $(\mathrm{df}=1)$. Differences $p<0.05$ were considered statistically significant [11].

\section{RESULTS AND THEIR DISCUSSION}

The conducted preliminary analysis of the complaints with which children from the first monitoring group were admitted to a children's hospital is presented in Figure 1. So, most often $65.3 \%(77 / 118)$ of children complained of a feeling of cardiac rhythm disturbance. Other complaints were registered as well: cardialgia $-17 \%(20 / 118)$ of cases; cephalgia $-9.3 \%$ (11/118); increase in blood pressure (hypertension) $-4.2 \%(5 / 118)$; syncopal states $-2.5 \%$

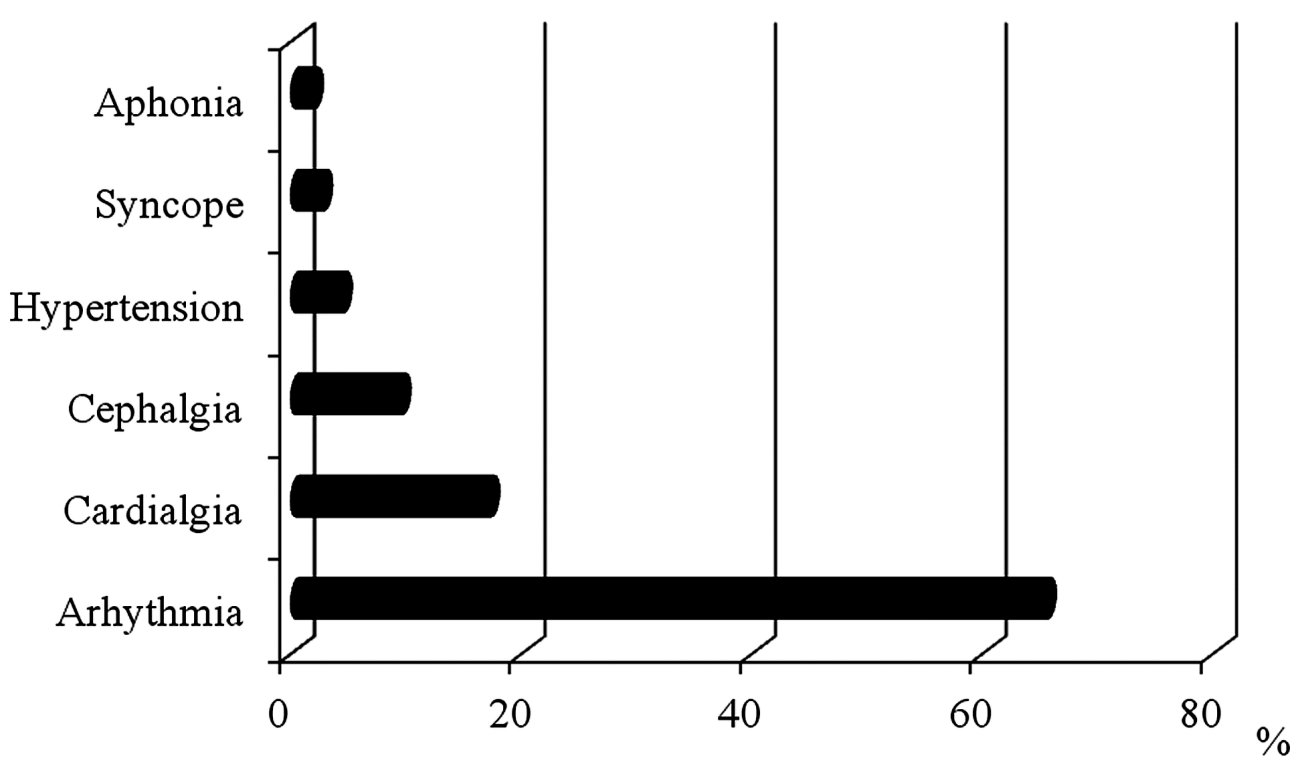

Fig. 1. Complaints of children with disturbed heart rhythm. 
(3/118); $1.7 \%(2 / 118)$ of children complained about aphonia. Complain comparison was not performed for children of the second group.

The organization and timely provision of medical assistance to children as well as diagnostic examination were carried out in accordance with the requirements of the current legislation of Ukraine in the field of health care. All children with complaints of cephalalgia and syncope were examined by a neurologist. Legal support of hospital health workers, children-patients and their parents regarding safe and effective examination and treatment, timely solution of various ethical and legal issues, namely, the mechanism of voluntary informed consent of parents or guardians of children for medical examination or treatment was conducted at the Department of Management and Pharmacy Economics, Medical and Pharmaceutical Commodity Research.

In the course of objective examination, electrocardiography testing and Holter monitoring, it was found that $61.86 \%(73 / 118)$ of children had nomotopic heart rhythm disturbances rhythm disturbances, $22.89 \%$ (27/118) patients had ectopic disturbances, and in $15.25 \%$ (18/118) of cases there were impaired conductivity in the form of atrioventricular blockade. Nomotopic violations of the heart rhythm: sinus arrhythmia - in $12.56 \%$ (16/118) of cases, sinus tachycardia $-24.58 \%(29 / 118)$, sinus bradycardia - $23.73 \%(28 / 118)$ of cases. Ectopic disturbances: sinus rhythm driver migration $-9.32 \%$ (11/118) of children and extrasystole $-13.56 \%$ (16/118) of children.

Abnormality of body weight were in $73.73 \%$ (87/118) children with violations of cardiac activity. Gender traits have also been traced. Thus, girls were more likely to report low body mass indexes than boys: $28.57 \%(18 / 63)$ against $3.64 \%(2 / 55), \mathrm{p}<0.05$. The increase in body weight was also significantly more common in girls: $33.33 \%(21 / 63)$ against $9.1 \%$ $(5 / 55)$ in boys. Children from group II had normal body mass.

According to ultrasound findings, ultrasound changes in the thyroid gland have been diagnosed in $55.93 \%(66 / 118)$ of children with heart rhythm disorders and in $12.5 \%(3 / 24)$ of children without cardiac disturbance. The results of the ultrasound examination of the thyroid gland are presented in Figure 2.

Thyroid gland volume, which differed from normal values, in relation to body surface area, was registered though significantly more in children with impaired cardiac rhythm than in children from Group II, but not adequate $(11.02 \%(13 / 118)$ against $4.17 \%(1 / 24)$ of children. Thus, in Group I, an increase in the amount of thyroid gland in relation to the body

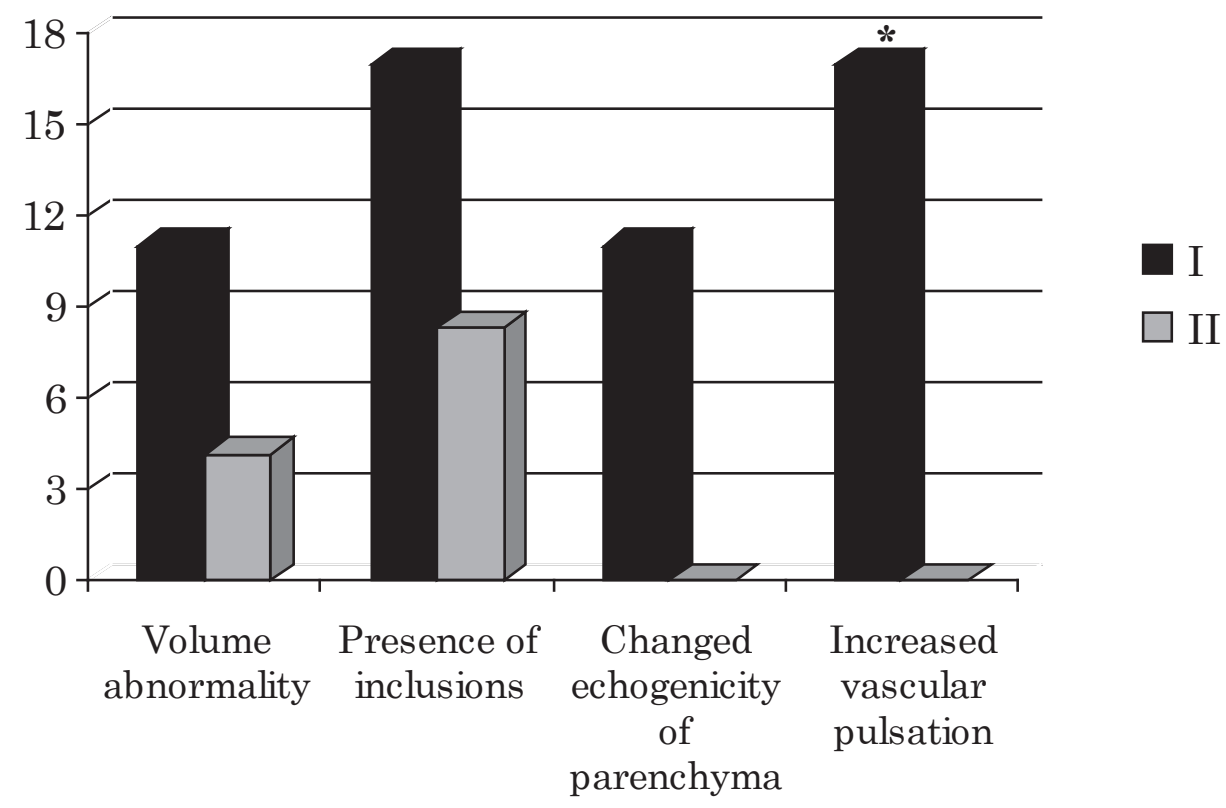

Fig. 2. Results of the ultrasound examination of the thyroid gland in children with heart rhythm disorders and children without cardiac disturbance, $\%$. * $-\mathrm{p}<0.05$ between I and II groups. 
surface area was recorded in $9.32 \%(11 / 118)$ of children with disturbed heart rhythm and the pronounced asymmetry, when the volume of one lobe less than the volume of the other by 2 times or more was noted in $1.7 \%(2 / 118)$ of children with disturbed heart rhythm. In one child (4.17\%) of the 2nd group of comparison was visualized thyroid volume increase.

Various pathological inclusions of various echogenicity (anechoic, hypo-, hetero- and hyperheric shadows, as ultrasound signs of follicles, cysts and nodes) were diagnosed in $16.95 \%$ (20/118) of children. In children with normal heart rhythm and asymptomatic course, pathological inclusions were visualized in $8.33 \%$ of cases.

Only in children with heart rhythm disorders ultrasound changes with an alternation in the echogenicity of the parenchyma of the thyroid gland were recorded in $11.02 \%(13 / 118)$ of cases and an increase in vascular pulsation with additional Doppler examination in $16.95 \%(20 / 118)$ of patients.

The results of ultrasound examination of the thyroid gland, depending on the nature of violations of cardiac activity, are presented in tables 1, 2, 3. Thus, pathological inclusions of the thyroid gland were significantly more often registered in children with malodorous heart rhythm disturbances (21.92\%). Also, the ultrasound changes in the thyroid gland were far more often registered in children with sinus tachycardia than in children with sinus arrhythmia (82.76\% versus 31.25 ), $p<0.05$.

Depending on age, among children with cardiac impairment and ultrasound changes in the thyroid gland, pathology of the thyroid gland was observed in $25.76 \%$ (17/66) of children under the age of 9 years and in $74.24 \%$ (49/66) of children from 10 to 17 years $(p<0.05)$. That is, ultrasound pathological changes of the thyroid gland were much more often registered among children from 10 years.

The prevalence of ultrasound changes in the thyroid gland in young children was approximately the same for patients of different sexes and amounted to $47.06 \%$ for girls and $52.94 \%$ for boys. From 10 years of age, of changes in the thyroid gland much more commoned in girls $(61.22 \%)$, which could be attributed to increased thyroid load in prepubertal and puberty periods than in boys (38.78\%).

Comparison of results of ultrasound examination of thyroid gland, taking into account the place of residence of patients, made it possible to draw attention to the fact that any violations in the ultrasound picture of the glands are often associated with living in an ecologically unfavorable area of the city. Thus, pathological changes in the thyroid gland were observed at

\section{Results of ultrasound examination of the thyroid gland in children,} depending on cardiac disorders (abs /\%)

\begin{tabular}{|c|c|c|c|c|}
\hline \multirow[b]{2}{*}{$\begin{array}{l}\text { Ultrasound } \\
\text { changes }\end{array}$} & \multicolumn{4}{|c|}{ Children with violation of cardiac activity } \\
\hline & $\begin{array}{c}\text { Nomotopic } \\
\text { rhythm } \\
\text { disturbances } \\
n=73\end{array}$ & $\begin{array}{c}\text { Ectopic } \\
\text { rhythm } \\
\text { disturbances } \\
n=27\end{array}$ & $\begin{array}{c}\text { Impaired } \\
\text { conductivity } \\
\mathbf{n}=18\end{array}$ & $\begin{array}{l}\text { Total } \\
\text { n = } 118\end{array}$ \\
\hline Volume abnormality & $\begin{array}{c}9 \\
12.33 \\
\end{array}$ & $\begin{array}{c}3 \\
11.11 \\
\end{array}$ & $\begin{array}{c}1 \\
5.56 \\
\end{array}$ & $\begin{array}{c}13 \\
11.02 \\
\end{array}$ \\
\hline Presence of inclusions & $\begin{array}{c}16^{*} \\
21.92 \\
\end{array}$ & $\begin{array}{c}4 \\
14.81 \\
\end{array}$ & $0 *$ & $\begin{array}{c}20 \\
16.95 \\
\end{array}$ \\
\hline Changed echogenicity of parenchyma & $\begin{array}{c}9 \\
12.33 \\
\end{array}$ & $\begin{array}{c}4 \\
14.81 \\
\end{array}$ & 0 & $\begin{array}{c}13 \\
11.02 \\
\end{array}$ \\
\hline Increased vascular pulsation & $\begin{array}{c}11 \\
15.07 \\
\end{array}$ & $\begin{array}{c}3 \\
11.11 \\
\end{array}$ & $\begin{array}{c}6 \\
33.33 \\
\end{array}$ & $\begin{array}{c}20 \\
16.95 \\
\end{array}$ \\
\hline Total & $\begin{array}{c}45 \\
61.64\end{array}$ & $\begin{array}{c}14 \\
51.85\end{array}$ & $\begin{array}{c}7 \\
38.89\end{array}$ & $\begin{array}{c}66 \\
55.93\end{array}$ \\
\hline
\end{tabular}

Note.

* the authenticity of the difference between the respective groups of children $(p<0.05)$. 
Results of ultrasound examination of the thyroid glandin children with nomotopic heart rhythm disturbances, (abs /\%)

\begin{tabular}{|c|c|c|c|c|}
\hline \multirow{2}{*}{$\begin{array}{l}\text { Ultrasound } \\
\text { changes }\end{array}$} & \multicolumn{4}{|c|}{ Nomotopic rhythm disturbances } \\
\hline & $\begin{array}{l}\text { Sinus arrhythmia } \\
\mathrm{n}=16\end{array}$ & $\begin{array}{c}\text { Sinus tachycardia } \\
n=29\end{array}$ & $\begin{array}{c}\text { Sinus bradycardia } \\
\mathrm{n}=28\end{array}$ & $\begin{array}{l}\text { Total } \\
\mathbf{n}=73\end{array}$ \\
\hline Volume abnormality & $\begin{array}{c}1 \\
6.25 \\
\end{array}$ & $\begin{array}{c}5 \\
17.24 \\
\end{array}$ & $\begin{array}{c}3 \\
10.71 \\
\end{array}$ & $\begin{array}{c}9 \\
12.33 \\
\end{array}$ \\
\hline Presence of inclusions & $\begin{array}{c}1 \\
6.25 \\
\end{array}$ & $\begin{array}{c}8 \\
27.59 \\
\end{array}$ & $\begin{array}{c}7 \\
25 \\
\end{array}$ & $\begin{array}{c}16 \\
21.92 \\
\end{array}$ \\
\hline $\begin{array}{c}\text { Changed echogenicity } \\
\text { of parenchyma }\end{array}$ & $\begin{array}{c}1 \\
6.25 \\
\end{array}$ & $\begin{array}{c}5 \\
17.24 \\
\end{array}$ & $\begin{array}{c}3 \\
10.71 \\
\end{array}$ & $\begin{array}{c}9 \\
12.33 \\
\end{array}$ \\
\hline $\begin{array}{c}\text { Increased vascular } \\
\text { pulsation }\end{array}$ & $\begin{array}{c}2 \\
12.5 \\
\end{array}$ & $\begin{array}{c}6 \\
20.69 \\
\end{array}$ & $\begin{array}{c}3 \\
10.71\end{array}$ & $\begin{array}{c}11 \\
15.07 \\
\end{array}$ \\
\hline Total & $\begin{array}{c}5^{*} \\
31.25\end{array}$ & $\begin{array}{c}24^{*} \\
82.76\end{array}$ & $\begin{array}{c}16 \\
57.14\end{array}$ & $\begin{array}{c}45 \\
61.64\end{array}$ \\
\hline
\end{tabular}

Note.

* the authenticity of the difference between the respective groups of children $(p<0.05)$.

Table 3

Results of ultrasound examination of the thyroid glandin children with ectopic heart rhythm disturbances, (abs /\%)

\begin{tabular}{c|c|c|c}
\hline \multirow{2}{*}{$\begin{array}{c}\text { Ultrasound } \\
\text { changes }\end{array}$} & \multicolumn{2}{|c}{ Ectopic heart rhythm disturbances } \\
\cline { 2 - 4 } & $\begin{array}{c}\text { Sinus rhythm driver } \\
\text { migration } \mathbf{n}=\mathbf{1 1}\end{array}$ & $\begin{array}{c}\text { Extrasystole } \\
\mathbf{n}=\mathbf{1 6}\end{array}$ & $\begin{array}{c}\text { Total } \\
\mathbf{n}=\mathbf{2 7}\end{array}$ \\
\hline Volume abnormality & 1 & 2 & 3 \\
Presence of inclusions & 9.09 & 12.5 & 4 \\
\hline Changed echogenicity of parenchyma & 1 & 3 & 11.11 \\
\hline Increased vascular pulsation & 9.09 & 3 & 4 \\
\hline Total & 1 & 18.75 & 14.81 \\
\hline \multirow{2}{*}{ (1) } & 1 & 2.09 & 3 \\
\hline
\end{tabular}

$78.79 \%$ of patients living in industrial areas of the city, while similar changes were diagnosed among children living in more environmentally friendly areas in $21.21 \%$ of patients $(\mathrm{p}<0.05)$.

Consequently, the evaluation of ultrasound changes in the thyroid gland in children with cardiac activity in different age groups has shown that it is worth increasing the intensity of diagnostic and preventative measures aimed at timely detection and prevention of thyroid gland diseases, and especially in children of prepubertal and pubertal age, who live in the most environmentally polluted areas.

\section{DISCUSSION}

The results of our studies are confirmed by the data of other scientists, namely that the patients with thyroid pathology often have symptoms indicating changes in the cardiovascular system, and complaints about heart rhythm di- sturbances (sinus tachycardia (42-78\%), supraventricular extrasystole (5-7\%), flutter (1.4\%), atrial fibrillation (5-7\%), other supraventricular and ventricular arrhythmias, bradycardia may be the only signs of the disease [12]. 
Having performed an ultrasound examination in 52 children with paroxysmal vegetative insufficiency, which was also characterized by a violation of the heart rhythm, Maydannyk V.H. with colleagues diagnosed and registered the thyroid gland heterogeneity in $66.7 \%$ of patients; changes in echogenicity - in 59.8\%; hypoechoic or hyperechoic inclusions - in $48 \%$, and macro-follicular masses or nodes - in 53\% [13].

Although the frequency of occurrence of nodules of the thyroid gland in children is much lower than in adults, nevertheless, the frequency of cases of malignant neoplasms of the thyroid gland with an increased risk of metastasis and relapse in children reaches $25 \%$ [14].

Today, Patrick Hanley and authors review the diagnostic capabilities of non-invasive ultrasound examination of the thyroid gland are quite high, since specialist see very good the inhomogeneous areas in the gland tissue, the foci of densification, cysts, thyroid hypoplasia or thyroid aplasia. For example, the prevalence of thyroid nodules increases with age; however, in contrast to adults, there is a higher rate of malignancy for nodules diagnosed in a patient younger than 19 years of age $(20 \%-25 \%$ vs $10 \%-15 \%$, respectively) [15].

Maria Segni also believes that ultrasound diagnostics provide enough information in case of nodal changes in the thyroid gland. Thus, in a study of 154 children and adults with goiter, nodules were diagnosed in $13 \%$. At the same time, papillary thyroid carcinoma sized up to $1.2-2.6 \mathrm{~cm}$ in diameter was diagnosed in $2.5 \%$ of cases, and biopsy was performed with the node sizes $>0.5 \mathrm{~cm}[16]$.

In case of autoimmune thyroiditis, heart problems also occur. Marco Cappa et al. showed that at ultrasound examination of the thyroid gland, the autoimmune thyroiditis was characterized by structural abnormalities in the form of generalized hypoechogenicity, and at a later stage of the disease - by diffuse fibrosis. This article reports that the single nodules were visualized in $60 \%$ of children with autoimmune thyroiditis, $40 \%$ of children had multiple nodules and only $3 \%$ of children had papillary carcinoma, although the incidence of thyroid cancer at autoimmune thyroiditis ranged from 1 to $30 \%$ [17].

Mirjana Barjaktarovic with colleagues in population children $(\mathrm{n}=4251$, median age 6 years, 95\% range: $5.7-8.0$ years) also proved associate between thyroid pathology with impaired function and cardio-vascular system. So, children with thyroid pathology have left ventricular mass was mean $53.8 \mathrm{~g}$ and systolic blood pressure - median 102 (95\% range 88-120) $\mathrm{mmHg}$ and diastolic blood pressure median 60 (95\% range 48-74) $\mathrm{mmHg}$ [18].

In addition to node visualization, an ultrasound examination often also shows an increase in the volume of the thyroid gland. However, Jozef Szczyrski and colleagues demonstrated that obese patients had a larger thyroid volume. Also, in obese children, the decreased echogenicity of the thyroid gland was recorded in $61 \%$ of cases, the echostructural changes in combination with the altered echogenicity - in $33 \%$, the isolated changes only in $9.2 \%$ of cases and the increase in blood flow - in $7 \%$.

The correlation was also found between the thyroid volume with body mass index and waist circumference, and after 6 months of diet and weight loss, the thyroid volume also decreased by $10 \%[19]$.

The presented data showed the importance and the need for screening ultrasound in children, especially those with heart rhythm disturbances being the first symptoms of thyroid diseases, including malignant tumors.

\section{CONCLUSIONS}

In ultrasound examination, pathological changes of the thyroid gland were recorded in $55.93 \%$ of children with heart rhythm disorders, more often in girls (61.22\%) aged 10 to 17 years of patients living in industrial areas of the city. So, for timely urgent issues timely early diagnostics of endocrine thyroid patho- logy, including cases of malignant neoplasms, it is necessary to conduct a screening ultrasound examination of the thyroid gland in children, and especially those with heart rhythm disorders living near large industrial enterprises and girls of prepubertal and pubertal age. 


\section{REFERENCES}

1. Dedov II, Mel'nichenko GA, Sviridenko NJu, et al. Problemy Jendokrinologii 2015; 1: 61-74.

2. Rustembekova SA, Tliashinova AM, Buraja TI, Sel'verova NB. Novye Issledovanija 2011; 28: 66-88.

3. Ivanova EV, Bogatyreva ZI, Isaeva MA. Terapevt Arh 2009; 81(10): 39-45.

4. Chikulaeva OA. Problemy Jendokrinologii 2014; 6: 53-66.

5. Kharchenko VP, Kotlyrov PM, Mogutov MS, et al. Hardcover 2010: 244 p.

6. Zelins'ka NB, Ostashko SI, Rudenko NG. Mezhdunar Jendokrinol Zhurn 2011; 3(35): 19-25.

7. Zelins'ka NB, Rudenko NG. Ukr Zhurn Dytjachoi' Endokrynologii' 2015; 2: 5-13.

8. Castellani MR, Seregni E, Maccauro M. QJ Nucl Med Mol Imaging 2008; 52: 430-440.

9. Shelkovoj JeA, Olijnyk VA, Matjashhuk SI. Liky Ukrainy 2010; 1(137): 60-65.

10. Brunn J, Block U, Rut G. Deutche Medicinische Wochen Schrift 1981; 106(41): 1338-1340.

11. Rebrova OJu. Statisticheskij analiz medicinskih dannyh. Primenenie paketa prikladnyh programm STATISTICA, Moskva, 2006: 312 p.
12. Karas' AS, Obrezan AG. Klin Jeksperim Tireoidologija 2009; 5(3): 37-42.

13. Majdannyk VG, Mytjurjaeva IO, Kuhta NM, et al. Sovremennaja Pediatrija 2014; 8(64): 119-125.

14. Essenmacher AC, Joyce PH, Kao SC, et al. RadioGraphics 2017; 37(6): 1731-1752. doi:10.1148/rg.2017170059.

15. Hanley P, Lord K, Bauer AJ. JAMA Pediatr 2016; 170(10): 1008-1019. doi:10.1001/jamapediatrics.2016.0486.

16. Segni M. Disorders of the Thyroid Gland in Infancy, Childhood and Adolescence, South Dartmouth, 2000, available at: https://www.ncbi.nlm.nih.gov/books/ NBK279032/.

17. Marco Cappa, Carla Bizzarri, Francesca Crea. J Thyroid Res 2011; 9: 13 p. doi: 10.4061/2011/675703.

18. Barjaktarovic M, Korevaar T, Gaillard R, et al. Eur $J$ Endocrinol 2017; 177: 319-327.

19. Szczyrski J, Kosiak W, Korpal-Szczyrska M. J Ultrason 2015; 15(63): 423-428. doi: 10.15557/JoU.2015.0039. 


\title{
ПОРІВНЯЛЬНА ХАРАКТЕРИСТИКА УЛЬТРАЗВУКОВИХ ЗМІН ЩИТОПОДІБНОЇ ЗАЛОЗИ У ДІТЕЙ \\ З ПОРУШЕНИМ ТА НОРМАЛЬНИМ РИТМОМ СЕРЦЯ
}

Шумна Т. Є., ${ }^{1}$ Недельська С. М. ${ }^{1}$, Шматко К. С. ${ }^{1}$, Алексеев О. Г. ${ }^{1}$, Жиленко I. О. ${ }^{1}$, Тарасевич T. В. ${ }^{1}$, Абрамова Т. В. ${ }^{1}$, Мережко А. С. ${ }^{2}$, Шапран А. В. ${ }^{2}$, Камагіна P. I. ${ }^{2}$

1 Запорізький державний медичний університет, м. Запоріжжя, Україна; ${ }^{2}$ КНП «Міська дитяча лікарня №5» Запорізької міської ради,

$$
\begin{aligned}
& \text { м. Запоріжжя, Україна } \\
& \text { tshumnaya72@gmail.com }
\end{aligned}
$$

Мета дослідження. Визначення та порівняльна характеристика ультразвукових змін щитоподібної залози у дітей з порушеним та нормальним ритмом серця для обгрунтування необхідності проведення скринінгового ультразвукового дослідження як засобу ранньої діагностики та профілактики тиреоїдної патології. Матеріали і методи. Ультразвукове дослідження щитоподібної залози було проведене у 142 дітей віком від 3 до 17 років. Із них, до I групи спостереження було включено 118 дітей 3 порушенням серцевого ритму, до II групи порівняння - 24 дитини 3 нормальним ритмом серця. Ультразвукова оцінка щитоподібної залози проводилась за допомогою ультразвукового aпарату eSaote MyLab50 з використанням лінійного датчика з частотою 7,5-12 МГц за загальноприйнятою методом Brunn, що полягає у визначенні під час ультразвукового дослідження трьох розмірів: довжини, ширини і висоти і визначення об'єму за формулою еліпсу $(0,479 \times \mathrm{A} \times \mathrm{B} \times \mathrm{C})$. Отримані результати дослідження були проаналізовані за допомогою непараметричних методів статистичного аналізу ліцензійного пакету програм «Statistica for Windows 6.1.RU», серійний номер AXXR712D833214SAN5. Результати. Патологічні зміни щитоподібної залози реєструвались у 55,9\% дітей з порушенням серцевого ритму (частіше із синусовою тахікардією) та у 12,5 \% дітей без порушення серцевої діяльності. У дітей 3 порушеннями серцевого ритму було діагностовано збільшення об'єму (9,32\%), асиметричне зменшення об'єму одніеї із долей $(1,7 \%)$, патологічні включення у вигляді тіней різної ехогенності $(16,95$ \%), зміни ехогенності паренхими (11,02 \%), підвищення судинної пульсації (16,95 \%). Серед дітей з нормальним ритмом серця із II групи, в 4,17 \% випадків реєструвалось збільшення об'єму, в 8,33 \% - патологічні включення щитоподібної залози. В залежності від віку та статі, ультразвукові зміни щитоподібної залози, рееструвались у 25,76 \% дітей до 9 років (у 47,06 \% дівчаток і 52,94 \% хлопчиків) і у 74,24 \% дітей від 10 до 17 років (у 61,22 \% дівчаток та 38,78 \% хлопчиків), а в залежності від місця проживання, у 78,79 \% пацієнтів, що мешкали в промислових районах міста та у 21,21 \% дітей, які мешкали у більш екологічно сприятливих районах. Висновок. Для вирішення актуальної проблеми своєчасної ранньої діагностики ендокринної тиреоїдної патології, в тому числі і випадків злоякісних новоутворень, всім дітям необхідно проводити обов'язкове скринінгове ультразвукове дослідження щитоподібної залози, а особливо, контингенту дітей з порушеннями серцевого ритму, що мешкають поблизу великих промислових підприемств та дівчаткам препубертатного і пубертатного віку.

К лючов і слов а : щитоподібна залоза, ультразвукова діагностика, ритм серця, діти.

\section{СРАВНИТЕЛЬНАЯ ХАРАКТЕРИСТИКА УЛЬТРАЗУКОВЫХ ИЗМЕНЕНИЙ ЩИТОВИДНОЙ ЖЕЛЕЗЫ У ДЕТЕЙ С НАРУШЕННЫМ И НОРМАЛЬНЫМ РИТМОМ СЕРДЦА}

\author{
Шумная Т. Е. ${ }^{1}$, Недельская С. Н. ${ }^{1}$, Шматко Е. С. ${ }^{1}$, Алексеев А. Г. ${ }^{1}$, Жиленко И. А. ${ }^{1}$, \\ Тарасевич Т. В. ${ }^{1}$, Абрамова Т. В. ${ }^{1}$, Мережко А. С. ${ }^{2}$, Шапран А. В. ${ }^{2}$, Камагина Р. И. ${ }^{2}$ \\ 1 Запорожский государственный медииинский університет, г. Запорожье, Украина; \\ ${ }^{2}$ КНП «Городская детская больница № 5" Запорожского городского совета, \\ г. Запорожье, Украина \\ tshumnaya72@gmail.com
}

Цель исследования. Определение и сравнительная характеристика ультразвуковых изменений щитовидной железы у детей с нарушенным и нормальным ритмом сердца для обоснования необходимости проведения скринингового ультразвукового исследования как способа ранней диагностики и профилактики тиреоидной патологии. Материалы и методы. Ультразвуковое исследование щитовидной железы было проведено у 142 детей в возрасте от 3 до 17 лет. Из них, в I группу наблюдения было включено 118 детей с нарушением сердечного ритма, во II группу сравнения - 24 ребенка с нормальным ритмом сердца. Ультразвуковая оценка щитовидной железы проводилась при помощи ультразвукового аппарата «еSaote MyLab50» с использованием линейного датчика с частотой 7,5-12 МГц по общепринятой методике Brunn, с определением во время ультразвукового исследования трех размеров: длины, ширины, высоты и определения объема по формуле элипса $(0,479 \times \mathrm{A} \times \mathrm{B} \times \mathrm{C})$. Полученные результаты исследования были проанализированы при помощи непараметрических методов статистического анализа лицензионного пакета программ "Statistica for Windows 6.1.RU», Statistical processing of data was carried out using conventional variational statistical methods using a licensed software package Statistica, серийный номер AXXR712D833214SAN5. Результаты. Патологические изменения щитовидной железы регистрировалась у 55,9 \% детей с нарушением сердечного ритма 
(чаще с синусовой тахикардией) и у 12,5 \% детей без нарушения сердечной деятельности. У детей с нарушениями сердечного ритма были диагностированы такие ультразвуковые изменения щитовидной железы: увеличение объема (9,32 \%), асимметричное уменьшение объема одной из долей (1,7 \%), патологические включения в виде теней разной эхогенности $(16,95 \%)$, изменения эхогенности паренхимы (11,02\%), повышение сосудистой пульсации (16,95 \%). Среди детей с нормальным ритмом сердца из II группы, в 4,17 \% случаев регистрировалось увеличение объема, в 8,33 \% - патологические включения щитовидной железы. В зависимости от возраста и пола, ультразвуковые изменения щитовидной железы, регитрировались у 25,76 \% детей до 9 лет (у 47,06 \% девочек и 52,94 \% мальчиков) и у 74,24 \% детей от 10 до 17 лет (у 61,22 \% девочек и 38,78 \% мальчиков), а в зависимости от места проживания, у 78,79 \% пациентов, проживающих в промышленных районах города и у 21,21 \% детей, проживающих в более экологически благоприятных районах. Выводы. Для решения актуальной проблемы своевременной ранней диагностики эндокринной тиреоидной патологии, в том числе и злокачественных новообразований, всем детям необходимо проводить обязательное скрининговое ультразвуковое исследование щитовидной железы, а особенно, контингенту детей с нарушением сердечного ритма, которые проживают вблизи крупных промышленных предприятий и девочкам препубертатного и пубертатного возраста.

К л ючевые с лов а : щитовидная железа, ультразвуковая диагностика, ритм сердца, дети.

\section{COMPARATIVE CHARACTERISTIC OF ULTRASOUND CHANGES OF THYROID GLAND IN CHILDREN WITH DISTURBED AND NORMAL HEART RHYTHM}

T. Ye. Shumna ${ }^{1}$, S. M. Nedelska ${ }^{1}$, K. S. Shmatko ${ }^{1}$, O. G. Alekseev ${ }^{1}$, I. O. Zhilenko ${ }^{1}$, T. V. Tarasevich ${ }^{1}$, T. V. Abramova ${ }^{1}$, A. S. Merezhko' , A. V. Shapran ${ }^{2}$, R. I. Kamagina ${ }^{2}$

${ }^{1}$ Zaporizhzhia State Medical University, Zaporizhzhia, Ukraine;

${ }^{2}$ Municipal Non-Profit Enterprise "City Children's Hospital № 5" of Zaporizhia City Council, Zaporizhzhia, Ukraine

tshumnaya72@gmail.com

Purpose. Determination and comparative characteristic of ultrasound changes of thyroid gland in children with disturbed and normal heart rhythm to justify the need for a ultrasound screening study as a method of early diagnosis and prevention of thyroid pathology. Materials and Methods. The ultrasound examination of the thyroid gland has been carried out for 142 children aged from 3 to 17 years old. Out of these number 118 children with cardiac rhythm disorders, were included in Observation group I, the second Comparative group included 24 children with normal heart rhythm. The ultrasound evaluation of the thyroid gland was performed using the ultrasound machine "Esaote MyLab50" with a linear sensor with a frequency of 7.5-12 $\mathrm{MHz}$ according to the generally accepted Brunn method, which consists of determining the three dimensions of the length, width and height of the ultrasound, and the determination of the volume by the formula of ellipse $(0,479 \times \mathrm{A} \times \mathrm{B} \times \mathrm{C})$. Statistical processing of data was carried out using conventional variational statistical methods using a licensed software package Statistica for Windows 6.1.RU, serial number AXXR712D833214SAN5. We used nonparametric statistical methods: the " $2 \times 2$ Table», the Chi-square $(\mathrm{df}=1)$. Differences $\mathrm{p}<0.05$ were considered statistically significant. Results. The pathological changes of the thyroid gland were recorded in $55.9 \%$ of children with heart rhythm disorders (more often with sinus tachycardia) and in $12.5 \%$ of children with normal heart rhythm. In children with heart rhythm disturbances, the following ultrasound changes in the thyroid gland were diagnosed: increased volume $(9.32 \%)$, asymmetric decrease of the volume of one of the thyroid lobes $(1,7 \%)$, pathological inclusions in the form of shadows of different echogenicity (16.95\%), changes in echogenicity of parenchyma (11.02\%), increased vascular pulsation (16.95\%). In group II, the $4.17 \%$ of children with thyroid volume increase and $8.33 \%$ of children with pathological inclusions in the thyroid gland, had normal heart rhythm. Ultrasound abnormalities of the thyroid gland were in $25.76 \%$ of children under 9 years of age (47.06 \% in girls and $52.94 \%$ in boys) and in $74.24 \%$ of children aged 10 to 17 years (61.22 \% in girls and $38.78 \%$ in boys) and diagnosed in $78.79 \%$ of patients living in industrial areas of the city and $21.21 \%$ of children living in more environmentally friendly areas. Conclusion. In ultrasound examination, pathological changes of the thyroid gland were recorded in $55.93 \%$ of children with heart rhythm disorders, more often in girls (61.22 \%) aged 10 to 17 years of patients living in industrial areas of the city. So, for timely urgent issues timely early diagnostics of endocrine thyroid pathology, including cases of malignant neoplasms, it is necessary to conduct a screening ultrasound examination of the thyroid gland in children, and especially those with heart rhythm disorders living near large industrial enterprises and girls of prepubertal and pubertal age.

Key words: thyroid gland, ultrasound diagnostics, heart rhythm, children. 